\title{
Relationship between profile characteristics and extent of precision in utilization of inputs by the rice farmers in Nellore district of Andhra Pradesh
}

\author{
C. Deepa*, P.V. Sathya Gopal, T. Lakshmi and S. Hemalatha \\ Department of Agricultural Extension, S.V. Agricultural College, Tirupati (A.P.) India \\ (Email: deepachede2015@gmail.com)
}

\begin{abstract}
The present investigation was done to study the relationship between profile characteristics and extent of precision in utilization of inputs by the rice farmers in Nellore district of Andhra Pradesh. Ex-post facto research design was followed for the study and a sample of 120 respondents was drawn. It was found that the computed ' $r$ ' values of the variables viz., education, extension contact, social participation, mass media exposure, management orientation, economic orientation and scientific orientation were more than the table value of " $r$ " at 0.01 level of significance and net returns was greater than the table value of " $r$ " at 0.05 level of significance and shown positively significant relationship with the extent of precision by the rice farmers. The computed ' $r$ ' values of the variables viz., age, farming experience, farm size and cost of cultivation were more than the table value of " $r$ " at 0.05 level of significance in a negative and show negatively significant relationship with the extent of precision by the rice farmers, relationship with the extent of precision by the rice farmers. On the other side, the computed ' $\mathrm{r}$ ' values of the variables viz., annual income, risk orientation, innovativeness, decision making ability and deferred gratification were less than the table value of " $\mathrm{r}$ " at 0.01 level of significance. Hence, it could be inferred that there was a non-significant relationship with the extent of precision by the rice farmers.
\end{abstract}

Key Words : Relationship, Extent of precision, Variables

View Point Article : Deepa, C., Sathya Gopal, P.V., Lakshmi, T. and Hemalatha, S. (2020). Relationship between profile characteristics and extent of precision in utilization of inputs by the rice farmers in Nellore district of Andhra Pradesh. Internat. J. agric. Sci., 16 (2) : 150-153, DOI:10.15740/HAS/IJAS/16.2/150-153. Copyright@2020: Hind Agri-Horticultural Society.

Article History : Received : 11.03.2020; Revised : 25.04.2020; Accepted : 01.05.2020

\footnotetext{
* Author for correspondence:
} 